Economica: Jurnal Ekonomi Islam - Volume 9, Nomor 1 (2018): 25 - 49

ISSN: 2085-9325 (print); 2541-4666 (online)

DOI: https://dx.doi.org/10.21580/economica.2018.9.1.2411

\title{
Literature Study on Murābaḥah Financing in Islamic Banking in Indonesia
}

\author{
Ahmad Maulidizen \\ Department of Shariah and Economics Academy of Islamic Studies, \\ University of Malaya \\ email: ahmadzen682@gmail.com
}

\begin{abstract}
Islamic banking in Indonesia has experienced significant growth, including assets, financing provided and the number of customers. Islamic bank financing $70-80 \%$ is given to the community by using the contract of murābahah, in the form of consumptive and productive. Islamic bank operations must be guided by Fatwa of the National Sharia Council in order to carry out its optimal function economically and to run the Shari'a comprehensively. Therefore, this article will explain the concept of muräbahah conceptually and application in Islamic banking in Indonesia. The purpose of writing this article so that the implementation of Murābahah contract in Islamic Bank in Indonesia can be in accordance with the principles of Shari'a that put forward the principle of justice and no party is harmed.
\end{abstract}

Keywords: Literature Study; Murābahahah Financing; Islamic Banking; Indonesia.

Abstrak: Perbankan syariah di Indonesia telah mengalami pertumbuhan yang signifikan, termasuk aset, pembiayaan yang diberikan dan jumlah pelanggan. Pembiayaan bank syariah $70-80 \%$ diberikan kepada masyarakat dengan menggunakan kontrak murābahah, dalam bentuk konsumtif dan produktif. Kegiatan banksyariah harus dipandu oleh Fatwa Dewan Syariah Nasional untuk menjalankan fungsi optimalnya secara ekonomis dan menjalankan syariat secara komprehensif. Oleh karena itu, artikel ini akan menjelaskan tentang konsep muräbahah secara konseptual dan aplikasinya pada Bank Islam di Indonesia. Tujuan penulisan artikel ini agar pelaksanaan kontrak Murābaḥah di Bank Syariah di Indonesia dapat sesuai dengan prinsip syariah yang mengedepankan asas keadilan dan tidak ada pihak yang dirugikan.

Kata Kunci: Studi Literatur; Pembiayaan Murābaḥah; Bank Islam; Indonesia.

Economica: Jurnal Ekonomi Islam - Volume 9, Nomor 1 (2018) 


\section{Introduction}

Sharia is the way of human life and was created to bring people to happiness in the world and the hereafter (falāh) through the enforcement of various appeals contained in the Qur'an and al-Hadith. The rules govern human life in various aspects, namely the field of 'ubūdiyah and mu'āmalah (Nasution 1986), (Maulidizen 2018). In addition to the principles of shari'ah economy as mentioned above, in Islamic law has also economic morality, known as the "golden five", namely justice, freedom, equality, participation, and accountability. Golden five is used as general principles underlying the principles of sharia (Tabari 2010). Like the conventional bank, sharia bank also functions as an intermediary institution, which is to collect funds from the community and channel the funds back to the community in need in the form of financing (Muhammad 2004). The philosophy of Islamic banking, financing should meet the aspects of sharia and economic aspects (Saeed 1999).

The most dominant financing done by the Islamic banking today is murābahah. This can be proven from several research result, it turns out that Islamic banking generally apply murābahah financing as the main financing that is $85 \%$. Since the beginning of 1984, in Pakistan muräbahah financing reached about $87 \%$. While in Dubai Islamic Bank, murābahah financing reached about $82 \%$. Even in the Islamic Development Bank (IDB), over a period of more than ten years of financing period 73\% of total financing is murābahah financing. In fact, actually Islamic banking has a superior product based on profit and loss sharing (PLS), namely muḍārabah and mushārakah.

Nevertheless, the mechanism of murābahah financing, it was not free from criticism of Muslim scholars. They argue that the Islamic banking in conducting its business activities, instead of eliminating interest and sharing risks, but retaining the practice of imposing interest with the label 'Islam' (Warde 2000). Among the jurists of fiqh, the validity of muräbahah financing is still debated. There are some scholars who allow because murābahah is a sale and purchase, but some scholars who forbid because it assumes that 
murābahah is not a sale but buy hilah to get ribā or usury. There are some scholars who regard it as ba'i al-inah which is unlawful, and some regard it as bai'atāni fi ba'iah (Qaraḍāwī 1987).

Based on the above problems, the purpose and objective of this article is to explain the concept of murābahah in the perspective of fiqh, murābahah in Islamic banking, and the offers the concept of pricing in murābahah products in Islamic banking as an alternative solution in fixing existing errors. This article is included in the library study, to obtain and collect reference materials in the form of documentation relating to the title raised in the writing, and then presented with qualitative descriptive method

\section{Research Methods}

This research is a library research with descriptive approach. That is to describe or explain the analysis of muräbahah financing in Islamic banking and offer a concept in determining price or margin as profit. Data collection methods in this study using documentation, then analyzed using inductive, deductive and comparative methods.

\section{Definition of Murābahah}

The word murābahah comes from the Arabic verb, rābaha, yurābihu, murābahatan. The original verb is from $f i$ 'il thulāthi is rabaha. In the dictionary of Lisān al-'Arab, the words al-ribhu, al-rabahu and al-rabbaḥu carry the same meaning of growth or growth in commerce (Ibn Manzūr 1954), (alFīyrūzābādī 1983). Whereas Ibn al-'Arabī states al-ribḥu and al-rabaḥu meaning profit in commerce. That takrifan combination brings to the notion al-ribh as an advantage of capital turnover generated through employment, trade and individual and collective transactions (Maulidizen 2016). While the murābahah is a word derived from the verb rābaha which intends to give mutual benefit between the buyer and the seller. However, if viewed from the commercial aspect, it only gives the seller and buyer benefits only, but from

Economica: Jurnal Ekonomi Islam - Volume 9, Nomor 1 (2018) 
other aspect, it still gives the buyer profit that is in the form of his intention to obtain and have something goods (Mansor and Fadhilah 2002)

Muräbahah is required to be one of the financing instruments based on al-Qur'ān dan al-Ḥadīth and ijma' (al-Kāsānī, n.d.). However, there is no Qur'anic verse and Hadīth Prophet Muhammad which directly concerns the murābahah, only found general guidance on the sale and purchase, profit, loss and commerce (Tamkin 1998), (Saeed 1999). The ulama define the murābahah with various forms of definitions but with the same relative intent. According to Ibn al-Humām, murābaḥah is a contract of delivery of a commercial merchandise possessed by a person, based on the cost of the original price of the first contract, and incremental gain, by informing the buyer (Ibn al-Humām 1970). Proportionate profits may be determined in the form of a certain amount of money or in the form of a certain percentage rather than the ratio of the purchase price, for example $10 \%$ or $20 \%$ (al-Sharbinì 1958), (Musjtari 2000), (Muhammad 2000).

Ibn Qudāmah gives a definition of a form of commerce that sells a good with a price of capital and adds a known profit (Ibn Qudāmah 1972), (alDasūqī, n.d.). Imām Mālik also explains that the murābahah is that if he sells something by taking a dirham for each dirham of issued capital or half dirham for every dirham he issued, or eleven dirhams for every ten dirhams of capital issuing, in terms of a little profit from capital or fortunately more than capital, depends on the agreement of both parties (al-Tanūkhi, n.d.). Imām Mālik bases the validity of the muräbahah with 'amalu ahli al-Madinah'. There is a consensus of opinion here (Medina) concerning the law of the person who bought the clothes in a city, and returns it to another city to sell it based on an agreement on profit. Imām al-Shāfi‘ī accept the validity of the murābahahah. He states: "If someone shows a commodity to someone and says, "You buy it for me, I will give you an advantage like this," then the person bought it, then the transaction is legal” (al-Shāfi'i 1968). 
Imām al-Nawawī, one of the scholar in the mazhab Shāfi'ī declares a murābaḥah "lawful" without argument (al-Nawawī 1991). Ibn Rushd defines the murābahah as buying and selling of goods at the price of capital in addition to the agreed benefits (Ibn Rushd 1988). Ulama Hanafi justify it under essential conditions for the validity of the sale in it, and also because humans need it (Saeed 1999). Thus murābahah is the sale of goods at a certain price which includes the purchase price and the profit margin and the price should be agreed by both contracting parties (Usmani 2002). By using the murābahah, the owner of the goods (the bank) makes a sale and purchase agreement with the customer. In this case the customer as a counselor pleads from the bank to buy an asset for him. The bank will purchase the desired asset and will sell to the customer at a price level that includes the initial cost and the additional profit as agreed by both parties (Sutedi 2009). The Customer will also pay in installments over a certain time period agreed upon without any interest imposed on the debt.

Thus, it can be understood that the current mechanism of the current muräbahah is the trading scheme of goods between the two parties on the basis of an agreement on prices that include the price of goods and profits. The Customer requests financing, to banks, financial institutions or cooperatives to purchase the desired assets and order the goods at the originating price mixed with the profits notified to the customer (al-Ashqar et al. 1998), (Haron 1996). In principle the murābahah has borrowed elements and is substituted for the concept of sale and purchase of goods, where the financier will notify the cost of ordering goods and profit taken from the customer. Therefore, on the basis of the added price, the profit becomes the selling price offered to the customer as the buyer who will pay the tough, gradually or simultaneously follow the agreement of both parties (Hamoud 1985). So we can conclude that, murābahah is the contract of sale and purchase of goods by stating the price of acquisition and profit (margin) agreed between the seller and the buyer (Sahroni 2016) (Karim 2004). While the price in the sale and purchase of the 
murābahah is the purchase price and the necessary costs plus the profit in accordance with the agreement (Susamto 2010).

\section{Requirements dan Term of Contract Murābaḥah}

Seeing the murābahah is one of the types of buy and sell contracts that is legal, then the terms and contracts of the muräbahah must meet the requirements for buying and selling in general, namely: (1) Two people who berakad (sellers and buyers) /al-'áqidāni, (2) Sighah akad (ijab and kabul) / sigghah, (3) Goods and prices / ma 'qüd 'alayh and al-thaman. In addition there are some special conditions for him, namely: (1) The seller should state the actual cost or capital of goods to be sold to the buyer, (2) The seller and the buyer agree on the amount of profit specified in addition to capital, of which both are (3) If there is a mistake in determining the actual quantity of the cost or capital of the goods, the buyer may cancel the contract, (4) The goods and the price shall not be from the goods of ribāwi which is happening the exchange of sale except to comply terms of exchange of goods ribāwi goods are to be sold in a murābahah it has been purchased from the producer, this first sale must be valid according to syarak (Usmani 2002), (Ibn Qudāmah 1972), (al-Kāsānī, n.d.), (al-Zuhailī 1989).

Given the five conditions mentioned above will provide a guarantee of validity of the contract and avoid the practice of ribā (Hasanin 1992). The fuqaha classify the murābahah in the category of buy buyü' al-amānah contracts because it is required that the seller when making this contract first declares the acquisition price of the goods he bought it before determining the selling price (Shubair 1998), (al-Zarqā 1968). If it is found that information about the acquisition price is incorrect, then the buyer has the right to make a choice (khiyār) to cancel or to continue it (Ibn Qudāmah 1972). Khiyār has goods with the correct price and appropriate or repatriate it. But if the item is no longer in the hands of the buyer, then he has no choice but to authorize the purchase (Ibn al-Humām 1970). After all, the seller is required to reduce the 
price or the difference in price without counting the goods still existing or alive (al-Sharbinì 1958). Although all mazhab of thought agree on the principle of murābahah as a legitimate tool and are justified in the business affairs, they argue about the details of their implementation, especially from the aspect of price determination and the level of profit. There are a handful of Islamic scholars and economists who question, deny or avoid the principle of murābahah used. Siddiqi, for example, questioned the use of instruments of murābahah by the Islamic banking as a tool of credit to customers who make the purchase of tough payments means giving the opportunity to the financier a pre-determined profit regardless of the risks.

From the aspect of price determination, scholars' of Ḥanāfî confirming the seller calculates the various expenses incurred in respect of the goods which become customary trade practices, mixed at the cost of the sale price (al-Jazīrī 2003). Hanbālī justify all shopping expenses related to the item is included in the determination of the selling price provided that every element of the shopping is notified to the buyer (al-Jazīrì 2003). The opinion of Shāfi'i similar to the Hanbali it's, just that they emphasize that the fees paid by the seller or the payout made to a third party any work that is not voluntary, should not be included in the price determination unless the buyer justifies it (Tamkin 1998).

Whereas Mālikì distribute the additional cost of the shopping to three categories: (1) All shopping that can be mixed with the capital price is a shopping that directly affects the goods. It becomes the basis for profit estimation, (2) Shopping that may be mixed with the price of capital but should not be the principle of profit estimation that is the shopping that does not give a direct impact on the goods, but forced to be issued because the seller did not do it alone, (3) Shopping is not a determination of the selling price and the principle of profit estimation that is the shopping that does not affect the goods and it can be done by the seller (al-Jazīrī 2003). 
In the context of the Islamic financial system, the use of the term murābahah is extended again, namely bay 'al- murābaḥah li al-āmir bi al-syirā' contract. Interpreted as one of the sale and purchase agreements between the seller (usually financial institution) with the customer in which the seller purchases the goods required by the customer who has a financing desire for the purpose of the purchase. Then the Bank will sell the goods to the customer at an agreed price, which gives a profit margin to the financial institution, with payments made by the customer in an agreed-upon or simultaneous time (Qal'ahjī 1997), (Ab Ghani 1999).

The idea of this type of contract has been introduced by Imām al-Shāfi‘ī earlier, and he was introduced by Sami Hamoud. The main features of bay ' $a l-$ murābaḥah li al-'âmir bi al-syirā' and the terms are as follows: (i) Promises which follow buyers or customers to finance or Bank to purchase ordered goods. The unauthorized customer is charged with any liability except to refine his pledge after he / she owns the order goods, (ii) It should be for Muslims to have it and it is or will be in the market, (iii) Sale and purchase contract between the Bank and the first seller that is, the owner of the goods, (iv) the sale and purchase in muräbahah contract between the Bank and the customer is made after the goods actually belong to the Bank. This is because it is the principle to allow the Bank to take advantage. If the payments are made in installments, the bank will raise the price of the goods because the payments are on hold (al-Mișrī 1977).

Banks are not justified at all raising the selling price or installment pay amount after being approved at the beginning of the contract. This buying and selling is called bay 'bi al-thaman äjil atau bay 'bi al-taqsitt (Qal'ahjī 1997). It is necessary to distinguish the period of time with the implementation of the business with the obligation of murābahah because it involves risks or guarantees to be borne by the Bank before the handing over of the customer (Hasanīn 1992). 
Literature Study on Murābaḥah Financing...

\section{The Legal Basis of Murābahah}

The majority of the fiqh schools state that muräbahah prescribed (required) because it includes general buying and selling. The legal basis of murābaḥah is as follows:

\section{Al-Qur'an}

The contract of murābahah, as described above, includes a sale and

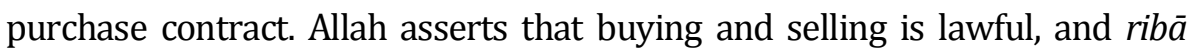
forbidden (al-Baqarah [2]: 275). Ibn al-Ḥumam, a faqih mazhab Ḥanafī declares that in the absence of a halt to a sale and purchase contract expressly mentioned in the verse, there is no need for any other proposition indicating the necessity of muräbahah. Because of the fact that the proposition of sale is absolutely absolute 'am, it is also the proposition of the necessity of murābahah (Ibn al-Ḥumām 1970). The Qur'an provides guidance that a transaction is only valid if each party involved in the transaction fulfills the obligation relating to the consequences of a transaction. For example, in a transaction in the form of a sale and purchase agreement, a buyer must pay an agreed amount, while the seller must deliver the goods he sells to the buyer (al-Ma'idah [5]: 2). And Someone who promises, must fulfill his promise (alIsra [17]: 34).

What is described in the verse, that the perfection of a covenant is an important obligation on the side of Islam. The Qur'an also mentions that all transactions should be made in the framework of mutual cooperation (alMa'idah [5]: 2). In another verse, Allah almighty orders to keep trust in all transactions, especially in matters relating to the scales (al-Isra [17]: 35). Every transaction must be done in the right way, mutually voluntary and avoiding vanity (al-Nisa' [4]: 29). In addition, in transactions of goods traded should be recognized by the principle of shari'ah (al-Ma'idah [5]: 4). Allah gives a stern warning against the perpetrators of transactions that commit deceit and deception (al-Muthaffifin [83]: 1-3).

Economica: Jurnal Ekonomi Islam - Volume 9, Nomor 1 (2018)

http://journal.walisongo.ac.id/index.php/economica 


\section{Al-Hadith}

There are some hadith which form the basis of the law of the validity of murābahah, although not directly indicating the type of contract of murābahah, which is (i) the hadith relating to the validity of contracting. The hadith is narrated by al-Bukhārī, Abū Dāwud and al-Tirmidhī that Prophet Muhammad said which means: "Muslims may enter into contract by making any condition but the conditions that justify the haram and forbid the lawful" (al-Tirmidhī 1967), (Ibn Taymiyyah, n.d.). (ii) Hadith about buying and selling is tough. From Suhayb al-Rūmī r.a that the Messenger of Allah (saws) said: "The three things in which there is blessing (ie): sell on hold, muqāradah (mudārabah), and mixing wheat with flour for home use, not for sale" (Ibn Mājah 1395). (iii) Hadith about ethics owe. From Ibn Abbas r.a that Prophet Muhammad said: "Whoever owes something, must follow certain limits and certain scales to a certain time period" (al-Bukhārī, n.d.). (iv) From Abī Sa'īd r.a, the Prophet Muhammad said: "Truly the buying and selling must be done likewise" (al-Albānī 1986).

\section{Methods of Fiqh}

Islam is a religion that is always suitable for all times and places. This Islamic nature is supported by legal instruments that make it flexible with all the changing times. Among them are in mu 'amalah. The scholars 'after understanding the philosophy underlying Islamic law, formulate a basic principle in mu'āmalat', which means "Your original law is that everything is permissible unless there is a prohibited prohibition (Qur'ān and Hadīth)" (alSuyūți 1399). This is based on the word of Allah saying: "Allah indeed has specified what is forbidden to you all” (al-An'am [6]: 119).

This means that everything that is haram has been detailed in shariah, while the mubāh (required) is not detailed in detail nor is it limited in detail. It is therefore possible in these recent times to adopt modern transactions that are not contrary to Sharia (al-Nadwī 1999). The parties who transact must 
always keep the transaction done does not cause harm to himself and others. As it is the case: "It is not lit and unlawful" (Al-Zarqā 2001).

\section{Fatwas of Ulama}

There are many scholar fatwas that point out the necessity of murābahah, like the fatwa of Baytal-Tamwìl al-Kuwaytī (Shaikh Badr al-Mutawallī 'Abd alBasiț), when asked about the bank's obligation to buy goods in cash, then he sells it to customers who request it at a higher price after taking into account operational costs. According to him, customer demand to buy to the bank is a promise. Although he acknowledged the difference of opinion of legal experts on the status of obligatory or not fulfill the promise, but he believes that the promise must be fulfilled because in addition to receiving the support of many traditions also make it easy for mankind. The first Islamic Finance Seminar in Dubai in May 1979 also stated that murābahah transactions contain promises from both financial institutions and customers that must be met by both parties (Qaraḍāwī 1987). Shaikh bin Baz declares that the transaction of murābahah is required if the goods sold have actually become the property of the Bank and the transfer of property takes place legally.

\section{Advantages and Risks Murābaḥah Financing}

The transaction of murābahah in accordance with commercial properties (tijärah) has several benefits, as well as the risks to be avoided. Murābahah Financing gives many benefits to the Islamic banking, one of which is the advantage that arises from the difference in the purchase price of the seller with the selling price to the customer. The risk of financing can be deducted to avoid greater losses by complying with various laws and regulations. Risks to avoid include (Maulidizen 2016):

a. Default or omission; customers deliberately do not pay installments.

Economica: Jurnal Ekonomi Islam - Volume 9, Nomor 1 (2018) 
b. Through the price rises fructuatif, this happens when the price of an item in the market rises after the bank bought it for the customer. Banks may not change the sale price.

c. Response of customers, goods sent can be rejected by the customer for various reasons. It could be because it is damaged in transit so customers do not receive, therefore it needs to be covered by insurance. Another possibility customers feel the specification of the goods is different from what he ordered.

\section{Murābaḥah In Islamic Banking}

Islamic banking has evolved and adopted various Islamic sales contracts to help finance their customers. These contracts are deeply expressed in sharia and developed through a long history by Islamic economic scholars. One of them is the buying and selling of murābahah, as practiced by Islamic banking. But in the modern world, the term is already an extension of its classical sense. Its application to Islamic banking is that customers apply financing with the system of muräbahah to Islamic banking to buy goods (productive and consumptive) that are known to its properties, where customers and banks know the goods are real and by the bank ready to hold goods required by customers. Then made a contract or agreement between the customer and the bank regarding the ability of the bank to buy the desired goods and the ability of customers to buy the goods. This contract is not a contract of sale, but a contract to hold a sale (Mujahidin 2016).

Murābahah, as used in Islamic banking, the principle is based on two main elements, namely the purchase price and associated costs, and the agreement on the mark-up (profit). Islamic banking adopts a murābahah to provide short-term financing to customers for the purchase of goods even though the customer has no money to pay. The basic characteristics of the contracts of muräbahah as sale and purchase with prepaid payments are as follows: (i) the buyer must have knowledge of the associated costs and the 
original price of the goods, and the mark-up shall be specified in the percentage form total price plus cost, (ii) what is sold is goods or commodities and paid with money, (iii) what is for sale and must be owned by every seller and the seller must be able to deliver the goods to the buyer, (iv) the payment is deferred. The murābahahah has understood here, is used in any financing where there are items that can be identified for sale (Saeed 1999).

Islamic banking techniques in the application of murābahah transactions is: (1) The Bank acts as a temporary seller of the customer as a buyer. The selling price is the purchase price of the bank from the manufacturer (factory) plus the profit (mark-up). Both parties must agree on the selling price and the terms of payment, (2) The sale price is included in the contract of sale and if it has been agreed, it can not change during the contract agreement. In banking, muräbahah is usually done by way of payment in installments, (3) In this transaction, if there is any goods delivered immediately to the customer, while the payment is done on a tough basis (Sudarsono 2004).

\section{Analysis Implementation of Murābaḥah In Islamic Banking}

Murābahah contracts executed by Islamic banking are a prime financing model with a financing portfolio of $70-80 \%$ when compared to other products. But in practice never escape from various problems, among them namely;

\section{Collateral}

In the context of lending to conventional banks, collateral plays an important role in ensuring loan repayments when they mature. It is different in the context of Islamic law (fiqh) that basically collateral is not a harmonious or absolute requirement fulfilled in the muräbahah and that assurance can be an inhibition in the flow of funds for small entrepreneurs. In essence, the guarantee is only intended to keep customers from playing with their orders. Therefore, the bank may ask for a guarantee to hold. In the technical operation 
of the goods ordered can be one of the acceptable guarantee for payment of debt (Sudarsono 2004).

As mentioned in the basic framework for the preparation and presentation of the Islamic banking Financial Statements that the bank may require the customer to provide collateral for the receivables of murti, among others, in the form of goods purchased from the bank. In addition, banks may request to urbun customers as a down payment on the contract when the parties agree. Urbun becomes part of repayment of the receipt of the murābahah when the murābahah so implemented. But if murābahah is canceled, urbun is discharged to the customer after deducting the loss with the agreement. If the down payment is less than the bank losses, then the bank may receive additional from the customer (Indriantoro 2002). Requesting a guarantee of debt is basically not a blameworthy thing. The Qur'ān commands Muslims to write down their debt and if necessary ask for guarantees for the debt. On several occasions, the Prophet gave his creditors credit for his debt. Warranties are one way to ensure that creditor rights will not be eliminated and to avoid taking up people's possessions in a vanity way (Saeed 1999).

\section{Responsibility of Risk}

Among the possible risks that occur in the contract of muräbahah that often cause problems and must be anticipated, among others: (1) Failure, the customer intentionally does not pay the installment, (2) Competitive price fluctuation, this occurs when the price of a good in the market rises after the bank buys it for the customer. The bank can not change the sale price, (3) customer refusal, goods sent may be rejected by the customer for cause. It could be because it is damaged in the way so customers do not want to accept it. Therefore, insurance should be protected. Another possibility is because customers feel the specifications of the goods are different from those ordered. When a bank has signed a purchase contract with its sale, the item will belong to the bank. Thus the bank has a risk to sell it to another party, (4) For sale, 
because muräbahah is buying and selling with debt, then when the contract is signed, the item belongs to the customer. The Customer is free to do anything to his property, including to sell it. If so, the risk of negligence will be great (Maulidizen 2016).

\section{Payment Delays}

If the postponement of debt payments is due to factors beyond the client's ability to control it, the sharia bank is morally obligated to reschedule the debt. On the other hand, if the customer is economically able to pay on time, but he does not, the sharia bank and its supervisory board have adopted the concept of "fines" to be imposed on customers. The amount of the fine will depend on the reasonable rate of return on the invested bank, which is the cost to cover the opportunity cost of capital. In some cases, if the repayment of the advance is not possible, the bank will seize collateral to cover the down payment (Saeed 1999).

Financing based on murābaḥah must be paid off within a certain period of time not much different from interest-based financing. However, there is the most fundamental difference between the two financing in the event that the debtor fails to pay off the debt at a predetermined time. Loans with interest, generally incur additional interest sanctions if the loan is not repaid at maturity. Meanwhile, in Islamic banking, the customer must be given tolerance time to pay off if he can't afford. Such delays must be granted, without incurring additional costs to the customer for the time given for payment. But for customers who are able to pay it off but they are negligent to pay off the debt on time, then Islamic banking apply the concept of "fine or penalty".

All of the above indicates that until the debt settlement, the Islamic banking has used the means to ensure that the debt is repaid on time, and if no 'losses' obtained by the bank are borne by the customer. Based on the above description, the role of Islamic banking in murābahahah as proposed by

Economica: Jurnal Ekonomi Islam - Volume 9, Nomor 1 (2018) 
Maulidizen, as a financier (not a seller). The bank does not hold the goods, nor take any risks on them. Bank work is almost entirely related to the handling of related documents and the sales contract is merely a formality. In addition, the determination of mark-ups in muräbaḥah contracts that are freely determined by the sharia bank, will be able to trigger the perception that mark-up is identical with interest. Therefore, it is necessary to study deeply about the concept of pricing in murābaḥah.

\section{Bankrupt}

If a borrowed customer is deemed to have failed to settle his debt, the bank must postpone the debt until the customer becomes able to repay it (Antonio 2001).

\section{Advantages Too High}

Based on the circumstances and the reason for the practice of murābahah in Islamic banking, there is some kind of condemnation or public judgment on the practice of Islamic banking not much different from conventional banks (interest banks). From the results of research conducted by Indonesian banks showed that $15 \%$ of respondents considered shariah banks are no different from conventional banks, just different wrap. Lay people also consider that Islamic banks in taking advantage of larger than conventional banks, because so far the layman judge that shariah financial institutions are always synonymous with cheap prices, so if there is a sale of goods by Islamic banks at a price higher than the sale price of banks conventional, the Sharia bank is considered more un-Islamic. Such a thing is very likely to happen, therefore, it is necessary to find the packaging of products of murābahah that provide a fair profit between the bank and the customer.

In practice, the high profit margin taken by the bank is to anticipate rising interest rates in the market or inflation, so that if there is a large interest rate increase, Islamic banking does not experience real losses, but if interest rates 
in the market remain stable or even down, the margin of muräbahah will be greater than the interest rate on the conventional bank (Muhammad 2004). Requests for purchases by customers are accompanied by a promise to purchase accompanied by advance payment to ensure that the customer is indeed serious in the purchase request and that he will complete his payment when the bank indicates the readiness to complete the sale and purchase transaction contract as soon as the bank reports that the goods are ready to be delivered or the documents regarding the goods have arrived. The sales contract will be finalized once the bank is notified by the supplier that the goods are ready to ship. Banks do not have to wait for the goods to be checked before they are handed over to the buyer. If there is a defect in handling, then the handicap is handled by the insurance company, whose insurance costs have been put into the total price of the goods and therefore borne by the buyer. The delivery courier is considered a bank representative in relation to the goods, then the buyer can solve all delivery problems with the courier, without dealing with the bank (Saeed 1999).

\section{The Pricing Concept In Murabahah Financing: An Alternative}

As noted above that the criticism of muräbahah financing provided by many Islamic scholars is that there is no fundamental difference between the mark-up in murābahah contracts in Islamic banking with interest in a loan loan in a conventional bank. Therefore, Islamic banking need to establish an appropriate and efficient method for murābaḥah financing to provide a fair profit between the Islamic banking with customers. Muräbaḥah financing is one form of natural certainty contract, because in murābahah determined how the required rate of profit. Natural certainty contract is a contract in the business that provides certainty of financing, both in terms of amount (amount) and time (timing). Cash flow can be predicted with relatively certain because it has been agreed by both parties who transact in the early akad. This contract offers a fixed and definite return. The object of the exchange, usually

Economica: Jurnal Ekonomi Islam - Volume 9, Nomor 1 (2018)

http://journal.walisongo.ac.id/index.php/economica 
in the form of goods, must be established at the beginning of the contract with certain amounts of good (quantity), quality, price and time of delivery. Islamic banking products included in this category are muräbahah and ijärah (Sahroni 2016), (Karim 2004). Determining the price on a contract that produces a natural profit (contract certainty), in most companies or banks, usually uses one of the methods: (Muhammad 2004)

\section{Mark-up Pricing}

The mark-up pricing method is the determination of the price level by increasing the product's cost of the commodity. In this method, a company or bank will sell its products at the price level of production cost plus the desired mark-up or margin.

\section{Target Return Pricing}

Target return pricing is the determination of product selling price that aims to get a return on the amount of invested capital, in financial language known as Return on Investment (ROI). In this case, the company or bank will determine how much expected return on invested capital.

\section{Perceived Value Pricing}

In contrast to the method of target return pricing that uses only the cost of production as a key to pricing, perceived value pricing also uses non-price variables as a basis for determining the selling price. In the perceived value pricing method, the pricing by not using the price variable as the basis of the selling price. The selling price is based on the price of the competitor's product in which the company or bank makes an addition or repair unit to increase the level of customer satisfaction. Thus, the company or bank can determine the price by considering the level of customer satisfaction of a commodity consumed. 
Literature Study on Murābaḥah Financing...

\section{Value Pricing}

It is a competitive pricing policy on high quality goods. As mentioned in the proverb Javanese "Ono rego ono ruppo". It has become a common understanding that good goods are expensive. But a successful company is a company that is able to produce quality goods with efficient cost so that the company can freely determine the price level below the price of competitors. Pricing in murābahah financing in Islamic banking may use one of the four models above. However, the determination of the selling price of Islamic banking products must continue to observe the provisions justified by sharia. Therefore, Islamic banking need to establish an appropriate and efficient method for murābahah financing to provide a fair profit between Islamic banking and the customers.

If the Islamic banking is to apply the method of mark-up pricing, then this method is only appropriate if used for financing the source of funds from Restricted Investment Account (RIA) or mudārabah muqayyadah. Therefore, the mark-up pricing method is not appropriate for use in muräbaḥah financing. Therefore, Islamic banking can apply the target return pricing target for murābahah financing. Because murābahah financing is done under a certain certainty contract, the method used is the required profit rate (rpr). In this case the high rpr is influenced by the profit level of each one transaction and the amount of transaction amount in a period. It should be noted, however, that the two variables, ie the profit rate and the large number of transactions, are only independent variables, whereas the actual profit rate is often influenced by other factors, such as the market price level (usually the bank also makes the interest rate as benchmark) in determining the desired profit level). The determination of the rpr value can be calculated using the following:

$$
\operatorname{rpr} \quad=n \cdot v
$$

Economica: Jurnal Ekonomi Islam - Volume 9, Nomor 1 (2018) http://journal.walisongo.ac.id/index.php/economica 


\section{Description:}

$$
\begin{array}{ll}
\mathrm{n} & =\text { profit rate in cash transactions } \\
\mathrm{v} & =\text { number of transactions in one period }
\end{array}
$$

Islamic banking practitioners need to be careful in applying the rpr method in Islamic banking. Because of the prevalence, the Sharia Bank also uses the market interest rate as a benchmark. Islamic banking should not only make the interest rate as a reference in determining the selling price (principal + margin). How to set margin that only refers to the interest rate as a benchmark is a heretical step as well as misleading and more severe can damage the reputation of Islamic banking.

In practice, perhaps the high profit margin taken by Islamic banking is to anticipate rising interest rates in the market (inflation). So if there is a large interest rate increase, then Islamic banking does not experience real losses. However, if interest rates in the market remain stable or even decreased, then the margin murābahah will be greater than the premises of interest rates in conventional banks. With the establishment of high profit margin muräbahah, indirectly will even cause inflation greater than that caused by interest. Therefore, it is necessary to find the right format so that the sale value with muräbahah does not refer to the anticipation of the interest rate increase during the period of payment of the installment. Because, linking murābahah profit margin with conventional bank interest, it is still not a good way (Muhammad 2004).

Determining the sale price murabahah, should be done premises how the Prophet when trading. This method can be used as one of the methods of Islamic banking in determining the sale price of murābahah products. The way the Prophet in determining the sale price is to explain the purchase price, how reasonable is desired. Are price fixing is based on cost plus mark-up (Muhammad 2004). Mathematically, according to Muhammad, murābaḥah 
sale price by cost plus mark-up method can be calculated by the following formula:

$$
\begin{array}{ll}
\text { Selling price } & =\text { Purchase price }+ \text { Cost Recovery }+ \text { Profit } \\
\text { Cost Recovery } & =\frac{\text { Estimated Operating Costs }}{\text { Target Financing Volume }} \\
\text { Margin } & =\frac{\text { Cost Recovery }+ \text { Profit x 100\% }}{\text { Purchase price }}
\end{array}
$$

Cost recovery is part of the estimated cost of operating the Islamic banking which is charged to the purchase price / total financing. The cost recovery can be approached by dividing the estimated operating cost with the targeted muräbahah financing volume, then added to the purchase price of the suppliers and the desired profit to obtain the selling price. While muräbahah margin obtained from cost recovery plus profit divided by Purchase price.

Percentage of margin above can be compared with interest rate. Thus, the interest rate is only used as a benchmark. In order for muräbahah financing to be more competitive, the murābahah margin must be less than the interest on the loan. If it is still bigger, then that should be played is to minimize the cost recovery and expected profit (Muhammad 2004). With this method, it is expected that the profit of Islamic banking will increase although with a smaller profit margin when compared with conventional bank loan interest. Another thing to note is that the margin calculation results listed in the murābaḥah financing are stated in nominal terms, not the percentage form.

\section{Conclusion}

From the whole discussion above, it can be concluded from this article, that is; murābahah is required to be one of the instruments of financing based on the reasons of the Qur'an, al-Hadith and ijma' ulama, although there is no Qur'anic verse or Prophetic traditions that directly explain murābahah, but there are general guidelines on trading, profits, losses and commerce. In

Economica: Jurnal Ekonomi Islam - Volume 9, Nomor 1 (2018) http://journal.walisongo.ac.id/index.php/economica 
summary, murābahah is defined as the sale of goods and the price is agreed by both contracting parties. Murābahah is one of the legalized contracts of sale and purchase. Therefore, the terms and principles of muräbahah contracts follow the terms of sale and purchase in general, namely: 2 people who settle an agreement or contract (al-'aqidāni) ie sellers and buyers, șigah contract, goods (ma'qūd 'alayh) and price (al-thaman), plus some special conditions. And the offer of pricing concept in muräbaḥah financing is expected to reflect the value of sharia in modern Islamic financial institutions. Because the presence of Islamic banking in the midst of society is expected to solve all the economic problems of the people. There needs to be improvement in the implementation of murābahah, so that it can fix any deficiencies that exist and attract people to use financial services.

\section{Bibliography}

Ab Ghani, Ab Mu'min. 1999. Sistem Kewangan Islam Dan Pelaksanaannya Di Malaysia. Kuala Lumpur: JAKIM.

al-Albānī, Muhammad Nāsir al-Dīn. 1986. Șahịḥ Al-Jāmī Al-Ṣaghīr Wa Ziyādatuh. Vol. 1. Beirut: al-Maktab al-Islāmī.

al-Ashqar, Muhammad Sulaimān, Muhammad Uthman Shabīr, Māiid Muhammad Abū Rakhiyyah, and 'Umar Sulaimān Al-Ashqār. 1998. Buhūth Fiqhiyyah Fī Qaḍāyā Iqtișādiyyah Mu'āṣirah. Vol. 1. Amman: Dār al-Nafă'is.

al-Bukhārī, Muhammad Ibn Ismāīll. n.d. Șahīḥal-Bukhārī. Vol. 3. Kairo: Dār alHadīth.

al-Dasūqī, Shams al-Dīn al-Shaikh Muhammad. n.d. Hāashiyah Al-Dasūqĩ 'alā AlSharh Al-Kabīr. Vol. 4. Beirūt: Dār al-Fikr.

al-Fīyrūzābādī. 1983. Al-Qāmūs Al-Muḥìt. 1st ed. Beirūt: Dār al-Fikr.

al-Jazīrī, 'Abd al-Rahmmān' bin Muhammad 'Aud. 2003. Al-Fiqh 'alā Al-Madhāhīb Al-'Arba'ah. 2nd ed. Beirut: Dār al-Kutub al-'Ilmiyyah.

al-Kāsānī, al-Imām 'Alā al-Dīn Abī Abu Bakr Ibn Mas'ūd. n.d. Badā'i' Al-Ṣanā'it' Fī Tartīb Al-Syarā'i'. Juz 5. Beirūt: Mațba'ah al-'Āṣimah. 
Literature Study on Murābaḥah Financing...

al-Mișrī, Rafiq Yūnus. 1977. Mașraf Al-Tanmiyat Al-Islāmī. Beirut: Mu’assasah al-Risālah.

al-Nadwī, 'Alī Ahmad. 1999. Mausū'ah Al-Qawā'id Wa Al-DawābițAl-Fiqhiyyah. Beirut: Dār 'Ālam al-Ma'rifah.

al-Nawawī, Abū Zakariyyā Muhyi al-Dīn bin Sharaf. 1991. Rawḍh Al-Ṭālibīn Wa 'Umdah Al-Muftīn. 3rd ed. Beirūt: al-Maktab al-Islāmī.

al-Shāfi'ī, Muhammad bin Idrīs. 1968. Al-Umm. Kairo: Dār al-Sha'b.

al-Sharbīnī, Muḥammad al-Khațīb. 1958. Mughnī Al-Muhtāj. Vol. 2. Kairo: Sharikah Maktabah wa Mațba'ah al-Muștafā al-Bābī al-Ḥalabī wa Awlādih.

al-Suyūțī, al-Imām Jalāl al-Dīn 'Abd. al-Raḥmān. 1399.Al-Asybāh Wa Al-Nāza'îr. Beirut: Dār al-Kutub al-'Ilmiyyah.

al-Tanūkhi, 'Abd al-Salām Ibn Sa'īd Ḥabīb Șaḥnūn. n.d. Al-Mudawwanah AlKubrā. Vol. 3. Beirut: Dār Șadīr.

al-Tirmidhī, Muhammad Ibn '̄̄sā. 1967. Sunan Al-Tirmidhī (Al-Jāmī Al-Sahịh). Vol. 3. Kairo: Maktabah al-Bābī al-'Ma'rifah al-Halabī.

al-Zarqā, Mușțafa Aḥmad. 1968. Al-Madkhal Al-Fiqhī Al-'Ām. Vol.1. Damaskus.

al-Zarqā, Shaikh Muḥammad. 2001. Sharḥ Al-Qawā id Al-Fiqhiyyah. Damaskus: Dār al-Qalam.

al-Zuhail̄̄, Wahbah. 1989. Al-Fiqh Al-Islāmī Wa 'Adillatuh. Vol. 3. Beirut: Dār alFikr.

Antonio, Muhammad Syafii. 2001. Bank Syariah: Dari Teori Ke Praktik. Jakarta: Gema Insani Press.

Hamoud, Sami. 1985. Islamic Banking. London: Arabian Information Ltd.

Haron, Sudin. 1996. Prinsip Dan Operasi Perbankan Islam. Kuala Lumpur: Berita Publishing Sdn Bhd.

Hasanīn, Fayyā 'Abd al-Mun'īm. 1992. Bay' Al-Murābaḥah Fī Al-Mașārif AlIslāmìyyah. Kairo: al-Ma'had al-Ālamī li al-Fikr al-Islāmī.

Ibn al-Ḥumām, al-Imām Kamāl al-Dīn 'Abd al-Rāḥid al-Sirāsi. 1970. Sharh Fatḥ Al-Qadīr. Vol. 5. Beirūt: Dār al-Kutub al-'Ilmiyyah.

Ibn Mājah, Muḥammad Ibn Yāzīd. 1395. Sunan Ibn Mājah. Vol. 2. Beirut: Dār Ihyā’ al-Turāth al-'Arabī.

Economica: Jurnal Ekonomi Islam - Volume 9, Nomor 1 (2018)

http://journal.walisongo.ac.id/index.php/economica 
Ibn Manẓūr, Abū al-Faḍl Jamāl al-Dīn Muhammad Ibn Mukarram. 1954. Lisān Al-'Arab. 4th ed. al-Qāhirah: al-Dār al-Mișriyyah li al-Ta'liff wa alTarjamah.

Ibn Qudāmah, 'Abd Allāh Ibn Aḥmad al-Maqdisī. 1972. Al-Mughnī Wa Al-Sharḥ Al-Kabìr. Vol. 4. Beirūt: Dār al-Kutub al-'Arabī.

Ibn Rushd, Muḥammad Ibn Aḥmad Ibn Muhammad. 1988. Bidāyah AlMujtahid Wa Nihāyah Al-Muqtașid. Vol. 2. Beirut: Dār al-Qalam.

Ibn Taymiyyah, Aḥmad bin 'Abd al-Ḥalīm bin 'Abd al-Salām. n.d. Naẓariyyah Al-'Aqd. Beirut: Dār al-Ma'rifah.

Indriantoro, Nur. 2002. Kerangka Dasar Penyusunan Dan Penyajian Laporan Keuangan Bank Syariah. Jakarta: Dewan Standar Akuntansi Keuangan Ikatan Akuntan Indonesia.

Karim, Adiwarman. 2004. Bank Islam: Analisis Fiqih Dan Keuangan. Jakarta: Rajawali Pers.

Mansor, Nor Azzah Kamri, and Fadhilah. 2002. "Aplikasi Konsep AlMurābahahah Dalam Penawaran Instrumen Di Institusi Perbankan Islam Di Malaysia." Prosiding Seminar Kewangan Islam. Kuala Lumpur.

Maulidizen, Ahmad. 2016. "Penjadualan Semula Pembiayaan Mikro Murābahahah Di Bank Syariah Mandiri, Indonesia." Universiti Malaya Kuala Lumpur.

-_ 2018. "A Critical Analysis of Islam, Economy, and Finance In The Early 21st Century." Hukum Islam 17 (2): 132-51. https://doi.org/10.24014/HI.V17I2.4984.

Muhammad. 2000. Sistem \& Prosedur Operasional Bank Syariah. Yogyakarta: UII Press.

- - - 2004. Manajemen Pembiayaan Bank Syariah. Yogyakarta: Unit Penerbit dan Percetakan AMP YKPN.

Mujahidin, Akhmad. 2016. Hukum Perbankan Syariah. Jakarta: Rajawali Press. Musjtari, Dewi Nurul. 2000. Penyelesaian Sengketa Operasional Bank Syariah. Yogyakarta: Nuha Medika.

Nasution, Harun. 1986. Akal Dan Wahyu Dalam Islam. Jakarta: UI Press.

Qal'ahjī, Muhammad Rawwās. 1997. Mabāhith Fī Al-Iqtișād Al-Islāmī. Beirut: Dār al-Nafā'is. 
Qaraḍāwī, Yūsuf. 1987. Bay' Al-Murābaḥah Li Al-'Amir Bi Al-Syirā' Kama Tajrīhī Al-Mașārif Al-Islāmiyyah. al-Qāhirah: Maktabah Wahbah.

Saeed, Abdullah. 1999. Islamic Banking and Interest: A Study of the Prohibition of Riba and Its Contemporary Interpretation. Netherlands: E.J. Brill.

Sahroni, Oni dan Adiwarman A. Karim. 2016. Maqhashid Bisnis \& Keuangan Islam: Sintesis Fikih Dan Ekonomi. Jakarta: Rajawali Press.

Shubair, Muhammad 'Uthmān. 1998. Al-Mu'āmalat Al-Māliyyah Al-Mu'āṣirah Fì Al-Fiqh Al-Islāmī. Beirut: Dār al-Nafā'is.

Sudarsono, Heri. 2004. Bank Dan Lembaga Keuangan Syariah, Deskripsi Dan Ilustrasi. 2nd ed. Yogyakarta: Ekoisia.

Susamto, Burhanuddin. 2010. Aspek Hukum Lembaga Keuangan Syariah. Yogyakarta: Graha Ilmu.

Sutedi, Adrian. 2009. Perbankan Syariah Tinjauan Dan Beberapa Segi Hukum. Bogor: Ghalia Indonesia.

Tabari, Nima Mersadi. 2010. "Islamic Finance and the Modern World: The Legal Principles Governing Islamic Finance in International Trade." The Company $\quad$ Lawyer $31 \quad$ (8): 249-54. https://papers.ssrn.com/sol3/papers.cfm?abstract_id=1740669.

Tamkin, Joni bin Borhan. 1998. "Bay Al-Murabahah in Islamic Commercial Law." Jurnal Syariah 6 (1): 55.

Usmani, Muhammad Taqi. 2002. An Introduction to Islamic Finance. London: Kluwer Law International.

Warde, Ibrahim. 2000. Islamic Finance in the Global Economy. Edinburgh: Edinburgh University Press. 
